(c) American Dairy Science Association, 2004.

\title{
Effects of Barley Silage Chop Length on Productivity and Rumen Conditions of Lactating Dairy Cows Fed a Total Mixed Ration
}

\author{
M. S. Einarson, J. C. Plaizier, and K. M. Wittenberg \\ Department of Animal Science, University of Manitoba, \\ Winnipeg, MB, Canada R3T 2N2
}

\begin{abstract}
Barley silage, cut at the early dough stage, was chopped long $(19 \mathrm{~mm})$ or short $(10 \mathrm{~mm})$, ensiled, and incorporated into total mixed rations (TMR). The TMR contained (dry matter [DM] basis) either 58.0 or $41.4 \%$ concentrate and either short- or long-chopped barley silage. Reducing chop length of barley silage decreased the proportion (as-is basis) of TMR particles retained by the 8 - and 19-mm screens of the Penn State Particle Separator (PSPS) from 66.9 to $52.7 \%$ in the high concentrate TMR and from 74.8 to $60.9 \%$ in the low concentrate TMR. Chop length reduction decreased dietary physically effective fiber, calculated as the NDF retained by the 8- and 19-mm screens of the PSPS, from 29.2 to $25.2 \% \mathrm{DM}$ in the high concentrate TMR and from 34.9 to $30.6 \% \mathrm{DM}$ in the low concentrate TMR. Reduction in chop length did not affect rumen $\mathrm{pH}$, total rumen volatile fatty acids, milk yield, and milk composition, but increased DM intake from 19.4 to $20.1 \mathrm{~kg} / \mathrm{d}$ at the high level of concentrate and from 16.9 to 17.7 $\mathrm{kg} / \mathrm{d}$ at the low level of concentrate and increased rumen propionate. Increasing the concentrate inclusion rate reduced rumen $\mathrm{pH}$ from 6.52 to 6.35 , did not affect total volatile fatty acids, reduced the acetate-to-propionate ratio from 3.1 to 2.7 , increased milk yield from 28.7 to $31.3 \mathrm{~kg} / \mathrm{d}$, reduced milk fat content from 3.48 to $2.94 \%$, and increased milk protein content from 3.11 to $3.27 \%$ across chop lengths.
\end{abstract}

(Key words: chop length, barley silage, physically effective neutral detergent fiber, dairy cow)

Abbreviation key: ADIP = acid detergent insoluble protein, $\mathbf{p e N D F}=$ physically effective NDF, $\mathbf{p e N D F}_{>}$ $\mathbf{1 . 1 8}=$ peNDF measured as the proportion of DM retained by a $1.18-\mathrm{mm}$ screen multiplied by dietary NDF, $\mathbf{p e N D F}_{\mathbf{M}}=$ peNDF measured from tabular values of chewing time, $\mathbf{p e N D F}_{\mathrm{NDF}}=$ proportion of dietary NDF retained by the $19-$ and $8-\mathrm{mm}$ PSPS screens,

Received March 14, 2004.

Accepted May 25, 2004.

Corresponding author: J. C. Plaizier; e-mail: plaizier@Ms. UManitoba.CA.
peNDF $_{\mathbf{P S}}=$ proportion of DM retained by the 19- and 8-mm PSPS screens multiplied by dietary NDF content, PSPS = Penn State Particle Separator.

\section{INTRODUCTION}

Milk production of dairy cows has increased dramatically during recent years. As a result, cows are fed high concentrate and low forage diets to meet the high nutritional demands. These diets have an upper limit of the concentrate-to-forage ratio, as a minimum amount of fiber is required for rumination and salivary rumen buffering (Beauchemin and Rode, 1997). Insufficient rumen-buffering capacity has a detrimental effect on the rumen, leading to subacute ruminal acidosis, milk fat depression, depressed fiber digestion, and laminitis (Mertens, 1997; Nocek, 1997; Krajcarski-Hunt et al., 2002). Conversely, including excess fiber in dairy cattle rations can reduce voluntary feed intake because of limitations of physical fill of the rumen (Allen, 2000).

Not all fiber sources are equal in their rumen-buffering capacity (Mertens, 1997). The amount as well as the physical and chemical characteristics of fiber in a diet affect animal performance (Mertens, 1997). It is, therefore, imperative that a validated unit or measure be established for the buffering capacity provided by a diet (Mertens, 1997). Physically effective NDF (peNDF) is a measure that reflects the ability of physical characteristics of fiber, mainly particle size, to stimulate chewing and saliva buffering in the rumen (Mertens, 1997). The National Research Council (2001) recommends a minimum of $25 \% \mathrm{DM}$ as NDF, of which $75 \%$ must be from forage sources. The NRC (2001) provides no recommendations for inclusion of peNDF because of the lack of a standard, validated technique to quantify the physically effective properties of fiber in a diet. The amount of peNDF in a diet is based on forage chop length, concentrate-to-forage ratio, and dietary NDF content (Mertens, 1997). The peNDF value of a feedstuff has been calculated as the product of the NDF content of the feed and the peNDF measured from tabular values of chewing time (peNDF $\mathbf{M}$; Mertens, 1997). Yang et al. (2001) determined peNDF measured as the proportion of DM retained by a 1.18-mm screen 
Table 1. Nutrient composition of the short- $(10 \mathrm{~mm})$ and long-chop $(19 \mathrm{~mm})$ barley silage included in the experimental diets.

\begin{tabular}{lcccc}
\hline & \multicolumn{2}{c}{ Barley silage } & \\
\cline { 2 - 3 } Chemical component $^{1}$ & Long chop & Short chop & SE & $P$ \\
\hline DM, \% & 20.4 & 25.0 & 0.55 & 0.007 \\
CP, \% DM & 13.8 & 11.7 & 0.70 & 0.08 \\
ADIP, \% DM & 0.95 & 1.10 & 0.15 & 0.52 \\
NDF, \% DM & 60.4 & 61.1 & 1.51 & 0.99 \\
ADF, \% DM & 37.9 & 38.3 & 1.23 & 0.82 \\
Ether extract, \% DM & 3.0 & 2.8 & 0.11 & 0.07 \\
Ash, \% DM & 12.3 & 12.9 & 0.15 & 0.85 \\
Ca, \% DM & 0.53 & 0.54 & 0.02 & 0.36 \\
P, \% DM & 0.39 & 0.32 & 0.12 & 0.11 \\
K, \% DM & 3.04 & 2.72 & 0.02 & 0.11 \\
Mg, \% DM & 0.35 & 0.40 & 0.01 & 0.002 \\
Na, \% DM & 0.14 & 0.09 & & \\
\hline
\end{tabular}

${ }^{1} \mathrm{n}=4$ for each forage.

${ }^{2} \mathrm{ADIP}=$ Acid detergent insoluble protein.

multiplied by dietary NDF (peNDF $>$ 1.18), using a dry sieving technique, as it was assumed that DM passing through a 1.18-mm screen would not stimulate chewing activity (Mertens, 1997). Yang et al. (2002) measured peNDF as a proportion of DM retained by the 19- and 8-mm Penn State Particle Separator (PSPS) screens multiplied by dietary NDF content (peNDF $\mathbf{P S}$ ). As NDF varies among PSPS fractions (Calberry et al., 2003), peNDF $_{\text {NDF }}$ has been determined as the amount of NDF retained on the 8- and 19-mm PSPS screens, multiplied by the respective DM percentage of the individual sieves (Calberry et al., 2003). It is yet unclear which measure of peNDF provides the most accurate estimate of chewing, saliva production, and rumen buffering (Yang et al., 2001; Beauchemin et al., 2003).

The suggested minimum requirements for peNDF $_{M}$ content in lactating dairy cattle diets is $22 \%$ of ration $\mathrm{DM}$, for maintenance of an average rumen $\mathrm{pH}$ of 6.0 , and $20 \%$ of ration DM for maintenance of a milk fat percentage of 3.4 in midlactation Holstein cows (Mertens, 1997). Minimum requirements for $\operatorname{peNDF}_{>1.18}$, peNDF $_{\mathrm{PS}}$, and peNDF $\mathrm{NDF}_{\mathrm{N}}$ have not yet been formulated; however, it has been suggested that these requirements depend on the forage source and the grain source of the diet, as forage and grains vary in NDF content, rumen degradability, and intrinsic rumen-buffering capacity (Beauchemin, 1991; Beauchemin and Rode, 1997; Soita et al., 2002). A recent survey of 40 randomly selected dairy farms across the province of Manitoba indicated that there is a shift to increased use of annual crops, predominantly barley, for silage in Western Canada (Plaizier et al., 2004). This necessitates the formulation of recommendations for peNDF contents of barley silage-based diets and chop length of barley silage.

The objectives of this experiment were to study the effect of varying barley silage chop length on dietary
peNDF, DMI, rumen fermentation, and milk production in dairy cows fed TMR at a high and a low concentrate inclusion.

\section{MATERIALS AND METHODS}

\section{Experimental Procedures}

Sixteen multiparious lactating Holstein cows housed in a tie-stall barn at the Glenlea Research Station, University of Manitoba, were used in a $4 \times 4$ Latin square design with four 3 -wk experimental periods. Each experimental period consisted of $14 \mathrm{~d}$ of adaptation to the experimental diet and $7 \mathrm{~d}$ of data collection. Animals were cared for in accordance with the Canadian Council for Animal Care guidelines. Upon commencement of the experiment, cows averaged $104 \pm 33.6$ DIM, had an average body condition score of $3.3 \pm 0.26$, and had an average BW of $620 \pm 62.8 \mathrm{~kg}$.

A Robust cultivar barley silage (Shanawan Farms, Domain, Manitoba, Canada) was harvested at the early dough stage and was chopped at 2 lengths, i.e., short chop (10 mm) and long chop (19 mm) using a New Holland Forage Harvester, model 790, from the same field on the same day. Both silages were ensiled in plastic-covered piles of approximately 30 tons without additives and inoculants for 3 mo prior to the beginning of the experiment.

The diets were mixed using a Data Ranger mixer (American Calan, Northwood, NH) with a Weigh Tronix weigh head (model 1000; American Calan).

Cows were assigned 1 of 4 TMR during each experimental period that had either a high concentrate inclusion $(43.3 \% \mathrm{DM}$ barley grain concentrate and $14.7 \%$ DM protein supplement) or a low concentrate inclusion (31.1\% DM barley grain concentrate and 9.3\% DM pro- 
tein supplement) and contained short-chop or long-chop barley silage (Table 1). As a result, diets were high concentrate, short chop; high concentrate, long chop; low concentrate, short chop; and low concentrate, long chop. The TMR were fed once daily for ad libitum consumption allowing for 5 to $10 \%$ orts. Cows had unlimited access to water.

\section{DMI and Feed Analyses}

During the collection periods, the amounts of TMR offered and refused were recorded daily for each cow. Diet samples were collected daily and pooled for each collection period. Individual cow ort samples were obtained daily during the collection period and pooled by weight and period. Forages were sampled once per collection period and pooled across collection periods. The DM content of pooled diets, forages, and ort samples were determined by drying at $60^{\circ} \mathrm{C}$ for $48 \mathrm{~h}$. Dried feed samples were ground using a Wiley mill through a 1-mm screen (Thomas-Wiley, Philadelphia, PA) and stored at $-20^{\circ} \mathrm{C}$ until analyzed.

All feed samples were analyzed for CP using the $\mathrm{CuSO}_{4} / \mathrm{TiO}_{2}$ Mixed Catalyst Kjeldahl procedure (988.05; AOAC, 1990), NDF (Van Soest et al., 1991) using $\alpha$ amylase (Sigma no. A3306; Sigma Chemical Co., St. Louis, MO), sodium sulfite corrected for ash concentration adapted for an Ankom 200 Fiber Analyzer (Ankom Technology, Fairport, NY), ADF (973.18; AOAC, 1990), ether extract (920.39; AOAC, 1990), ash (942.05; AOAC, 1990), and starch (McRae and Armstrong, 1968). Calcium, $\mathrm{P}, \mathrm{K}, \mathrm{Mg}$, and $\mathrm{Na}$ were measured by inductively coupled plasma emission spectroscopy (968.08; AOAC, 1990) using an Atom Scan 25 plasma spectrometer (Thermo Jarrell Ash Corp., Grand Junction, CO) after acid digestion. Acid detergent insoluble protein (ADIP) was determined by measuring the $\mathrm{CP}$ (988.05; AOAC, 1990) in the ADF fraction (973.18; AOAC, 1990).

Particle size distributions were determined for all TMR, pooled orts, and forage samples using the PSPS (Heinrichs, 1996). The PSPS had 2 screens and a bottom pan. The diameters of holes of the screens were 19 and $8 \mathrm{~mm}$ for the top and middle screens, respectively. Approximately $150 \mathrm{~g}$ of wet sample were placed on the top screen of the PSPS. The PSPS was shaken a total of 40 times ( 5 times in each direction, twice) (Heinrichs, 1996). The contents of each fraction were weighed and analyzed for DM and NDF as described earlier.

\section{Milk Yield and Composition Analyses}

Cows were milked twice daily, and milk production was determined using Tru Test regulation meters
(Westfalia Surge, Mississauga, Ontario, Canada). Milk samples were collected from 4 consecutive milkings in 50 -mL vials on the fourth and fifth day of each collection period and preserved with 2-bromo-2-nitropropane-1,3 diol. Milk samples were stored at $4^{\circ} \mathrm{C}$ until analyzed for fat and protein at the laboratory of the Manitoba Milk Producers (Winnipeg, Manitoba, Canada) by near infrared analysis using the Milk-O-Scan 303AB (Foss Electric, Hillerød, Denmark).

\section{Rumen pH Measurement}

Rumen fluid was sampled during d 4 and 6 of each collection period at 4 to $5 \mathrm{~h}$ postfeeding. Approximately $50 \mathrm{~mL}$ of fluid were aspirated using a Geishauser oral probe (Duffield et al., 2004). Rumen fluid pH was measured using an Accumet Basic $15 \mathrm{pH}$ meter and an Accumet gel-filled polymer body combination $\mathrm{pH}$ electrode (Fisher Scientific, Fairlawn, NJ) calibrated with pH 4.0 and 7.0 buffer solutions (Fisher Scientific). Rumen fluid samples were centrifuged at $1900 \times g$ for 10 min, and the supernatant was stored at $-20^{\circ} \mathrm{C}$ until further analysis.

\section{VFA and Ammonia Analyses}

Frozen rumen fluid samples were thawed at room temperature, and $1 \mathrm{~mL}$ of a $25 \%$ meta-phosphoric acid solution was added to $5 \mathrm{~mL}$ of rumen fluid. The tubes were vortexed and placed in a $-20^{\circ} \mathrm{C}$ freezer for $17 \mathrm{~h}$. Thawed samples were centrifuged for $10 \mathrm{~min}$ at 1900 $\times$ g. Approximately $2 \mathrm{~mL}$ of supernatant were decanted into a clean dry vial. The samples were capped and placed into the autosampler device (model 8100; Varian, Walnut Creek, CA) for analysis. Concentrations of VFA were determined by gas chromatography (model 3400 Star; Varian) using a 1.83-m glass column (model 2 to 1721; Supelco, Oakville, Ontario, Canada) (Erwin et al., 1961). The injector and detector temperatures were set at 170 and 195, with initial and final column temperatures set at $120^{\circ} \mathrm{C}$ and $165^{\circ} \mathrm{C}$, respectively. The run time was 4 min followed by a 2 -min thermal stabilization period.

Ammonia nitrogen concentration of rumen fluid samples was determined using the method described by Novozamsky et al. (1974). Absorbance was read at 630 $\mathrm{nm}$ on a Pharmacia Biotech Ultraspec 2000 UV/visible spectrophotometer (Biochrom, Cambridge, UK).

\section{Statistical Analysis}

Data (weekly averages of rumen fluid, milk, and intakes) were used for ANOVA using the SAS Mixed Models procedure (SAS, 1990). The effects of chop length 
Table 2. Ingredients and nutrient composition of experimental diets with high or low concentrate inclusion and short $(10 \mathrm{~mm})$ or long $(19 \mathrm{~mm})$ chop length of barley silage. ${ }^{1}$

\begin{tabular}{|c|c|c|c|c|c|c|c|}
\hline \multirow[b]{2}{*}{ Diet ingredient } & \multicolumn{4}{|c|}{$\operatorname{Diet}^{1}$} & \multirow[b]{2}{*}{ SE } & \multicolumn{2}{|c|}{ Effect } \\
\hline & HSC & HLC & LSC & LLC & & Chop & Concentrate \\
\hline Long-chop barley silage, \% & 0 & 42.0 & 0 & 58.6 & - & - & - \\
\hline Short-chop barley silage, \% & 42.0 & 0 & 58.6 & 0 & - & - & - \\
\hline Energy supplement, $\%$ & 43.3 & 43.3 & 32.1 & 32.1 & - & - & - \\
\hline \multirow{2}{*}{\multicolumn{8}{|c|}{$\begin{array}{l}\text { Protein supplement, } \% \\
\text { Nutrient composition }{ }^{2}\end{array}$}} \\
\hline & & & & & & & \\
\hline $\mathrm{DM}, \%$ & 43.2 & 40.4 & 35.8 & 33.0 & 0.40 & $<0.0001$ & $<0.0001$ \\
\hline $\mathrm{CP}, \% \mathrm{DM}$ & 18.0 & 20.1 & 17.3 & 18.2 & 0.31 & 0.0005 & 0.002 \\
\hline NDF, \% DM & 42.3 & 44.1 & 48.1 & 47.1 & 0.88 & 0.67 & 0.0005 \\
\hline $\mathrm{ADF}, \% \mathrm{DM}$ & 24.0 & 23.6 & 28.0 & 27.1 & 0.63 & 0.32 & $<0.0001$ \\
\hline Starch, \% DM & 18.0 & 17.0 & 14.7 & 13.5 & 0.56 & 0.21 & 0.002 \\
\hline $\mathrm{Ca}, \% \mathrm{DM}$ & 1.25 & 1.29 & 1.05 & 1.04 & 0.06 & 0.84 & 0.003 \\
\hline $\mathrm{P}, \% \mathrm{DM}$ & 0.62 & 0.68 & 0.55 & 0.55 & 0.02 & 0.20 & 0.003 \\
\hline $\mathrm{K}, \% \mathrm{DM}$ & 1.85 & 1.85 & 2.21 & 2.19 & 0.10 & 0.92 & 0.003 \\
\hline $\mathrm{Mg}, \% \mathrm{DM}$ & 0.41 & 0.38 & 0.40 & 0.38 & 0.02 & 0.17 & 0.66 \\
\hline $\mathrm{Na}, \% \mathrm{DM}$ & 0.50 & 0.55 & 0.39 & 0.42 & 0.03 & 0.11 & 0.002 \\
\hline
\end{tabular}

${ }^{1} \mathrm{HSC}=$ High concentrate, short chop; HLC = high concentrate, long chop; LSC = low concentrate, short chop; LLC = low concentrate, long chop.

${ }^{2} \mathrm{n}=4$ for each treatment.

and level of concentrate inclusion were considered fixed effects. The effects of cow and period were considered random. Statistical significance was set at a $P$ value of $\leq 0.05$. Differences between treatment means were established using Tukey's multiple range test (SAS, 1990). Reported SE are those used for the comparison of treatment means.

\section{RESULTS AND DISCUSSION}

\section{Chemical and Physical Compositions of Forage Ingredients and Experimental Diets}

The DM content was greater $(P=0.0007)$, and CP content was lower $(P=0.08)$, in the short-chop barley silage compared with the long-chop barley silage (Table 1). Dietary NDF, ADF, ether extract, ash, and macrominerals did not differ between short-chop and longchop barley silage. As a result, diets based on shortchop barley silage had higher $(P<0.0001) \mathrm{DM}$ and lower $(P=0.0005) \mathrm{CP}$ than diets based on long-chop barley silage (Table 2). Increasing dietary concentrate increased dietary DM $(P<0.0001), \mathrm{CP}(P=0.002)$, and starch $(P=0.002)$ and decreased dietary $\mathrm{NDF}(P=$ $0.0005)$ and $\operatorname{ADF}(P<0.0001)$. The composition of the concentrate components is given in Table 3.

Long-chop barley silage had considerably fewer particles passing through the 8- and 19-mm PSPS screens than the short-chop barley silage (Table 4). As a result, diets that incorporated the long-chop barley silage had less $(P=0.0003) \mathrm{DM}$ passing through the $8-\mathrm{mm}$ screen of the PSPS and more $(P=0.006) \mathrm{DM}$ retained by the $19-\mathrm{mm}$ screen (Table 5) than diets incorporating the short-chop barley silage. Increasing the level of dietary concentrate increased $(P=0.007)$ the amount of DM passing through the 8-mm screen and decreased $(P=$ 0.0004 ) the amount of DM retained on the $19-\mathrm{mm}$ screen. Long-chop silage doubled DM retained in the top PSPS screen for the high concentrate diet; the increase was even greater for the low concentrate diet. Content of NDF was higher $(P=0.003)$ in the top screen

Table 3. Ingredient composition of energy supplement and protein supplement (\% DM).

\begin{tabular}{|c|c|c|}
\hline Ingredient & $\begin{array}{l}\text { Energy } \\
\text { supplement }\end{array}$ & $\begin{array}{l}\text { Protein } \\
\text { supplement }\end{array}$ \\
\hline Rolled barley & 54.0 & - \\
\hline $\begin{array}{l}\text { Luprosil salt } \\
\text { (calcium propionate) }\end{array}$ & 0.2 & - \\
\hline Protein pellet ${ }^{1}$ & 1.8 & - \\
\hline Dairy supplement ${ }^{2}$ & 40.0 & - \\
\hline $\begin{array}{l}\text { Tallow } \\
\text { (feed grade rendered fat) }\end{array}$ & 4.0 & \\
\hline Dried distillers grain & - & 42.0 \\
\hline Fish meal & - & 7.0 \\
\hline Canola meal & - & 22.8 \\
\hline Soybean meal & - & 20.0 \\
\hline Beet molasses & - & 3.2 \\
\hline Niacin (vitamin $B_{3}$ ) & - & 0.3 \\
\hline Sodium bicarbonate & - & 5.0 \\
\hline
\end{tabular}

${ }^{1}$ Protein pellets contained $46.1 \%$ soybean meal, $2.6 \%$ wheat shorts, $40.0 \%$ canola meal, $5.0 \%$ oat hulls, $0.3 \%$ pellet binder, $1.0 \%$ cane molasses, and $5.0 \%$ corn gluten meal.

${ }^{2}$ Dairy supplement contained $0.13 \%$ vitamin A, D, and E premix (vitamin A, 16,800 IU/kg; vitamin D, 2215 IU/kg; vitamin E, 75 IU/ $\mathrm{kg}$; DM basis), $0.13 \%$ trace mineral premix, $2.6 \%$ soybean meal, $0.06 \%$ selenium, $39.1 \%$ wheat shorts, $5.0 \%$ distillers grain, $17.5 \%$ canola meal, $15.0 \%$ ground wheat, $1.7 \%$ dicalcium phosphate, $1.6 \%$ salt, $2.0 \%$ dynamate, $0.3 \%$ pellet binder, $1.0 \%$ cane molasses, $3.7 \%$ calcium carbonate, and $10.0 \%$ corn gluten meal. 
Table 4. Penn State particle size analysis of long- $(19 \mathrm{~mm})$ and shortchop $(10 \mathrm{~mm})$ barley silages (SD are presented in parentheses).

\begin{tabular}{lcc}
\hline & \multicolumn{2}{c}{ Barley silage } \\
\cline { 2 - 3 } PSPS sieving $^{1}$ & Long chop & Short chop \\
\hline & $37.1(5.81)$ & $12.9(3.75)$ \\
Top screen $(>19 \mathrm{~mm})$ & $55.9(5.17)$ & $60.3(2.68)$ \\
Middle screen $(>8 \mathrm{~mm})$ & $7.0(0.72)$ & $26.8(5.33)$ \\
Bottom pan & & $(\%$ retained; DM basis $)$ \\
& $34.3(7.74)$ & $9.0(3.06)$ \\
Top screen $(>19 \mathrm{~mm})$ & $60.8(7.36)$ & $68.6(6.06)$ \\
Middle screen $(>8 \mathrm{~mm})$ & $4.8(0.45)$ & $22.4(6.01)$ \\
Bottom pan &
\end{tabular}

${ }^{1} \mathrm{n}=4$ for each forage.

of the PSPS than in the bottom pan fraction of the PSPS (Table 5), which caused diets to have lower values for peNDF $_{\mathrm{PS}}$ than for peNDF $\mathrm{NDF}_{\mathrm{N}}$. At the high concentrate inclusion, reduction in chop length reduced peNDF ${ }_{\mathrm{PS}}$ and peNDF ${ }_{\mathrm{NDF}}$ from 21.1 to $18.9 \% \mathrm{DM}$ and from 29.2 to $25.2 \% \mathrm{DM}(P=0.007)$, respectively. At the low concentrate inclusion, reduction in chop length reduced peNDF $_{\mathrm{PS}}$ and peNDF ${ }_{\mathrm{NDF}}$ from 29.5 to $24.6 \% \mathrm{DM}(P=$ $0.002)$ and from 34.9 to $30.6 \% \mathrm{DM}(P=0.007)$, respectively.

The diets used in this experiment exceeded the NRC (2001) minimum NDF recommendation of $25 \%$ dietary DM, with $75 \%$ of NDF from forage. The diets used in this experiment also exceeded the current recommendations for minimum NDF content, which is $34 \% \mathrm{DM}$ in barley silage-based diets as established by Beauchemin (1991). Heinrichs (1996) recommended that on a wet basis the $19-\mathrm{mm}$ sieve, the $8-\mathrm{mm}$ sieve, and the bottom pan of the PSPS should retain 6 to 10\%, 30 to 50\%, and 40 to $60 \%$, respectively, of TMR. In the current experiment, all diets were coarser than these guidelines, with the exception of diet with a high concentrate proportion and short-chop barley silage, which was on par with these recommendations. In a comparison of particle size distribution of TMR and their orts, orts had a larger percentage of DM retained by the $19-\mathrm{mm}$ screen of the PSPS than TMR (Figure 1). This was also observed by Calberry et al. (2003), who demonstrated that cows selected against large feed particles in favor of small feed particles.

The DM content of the barley silage was lower than that of the barley silages used in the studies from Soita et al. (2000) and Koenig et al. (2003). The short-chop barley silage used in this experiment had a higher DM content than the long-chop barley silage (Table 3). This might have been the result of a slightly longer wilting time for the long-chop barley silage compared with the short-chop barley silage, as the long-chop barley was chopped and ensiled first.

The high moisture content of the barley silage did not result in poor quality silage. An indicator for silage quality is the dietary ADIP content. High ADIP contents are an indication of low moisture content promoting excessive heating and aerobic fermentation, resulting in a reduced availability of dietary $\mathrm{N}$ (Khora-

Table 5. Penn State Particle Separator analysis of experimental diets with high $(58.0 \% \mathrm{DM})$ or low concentrate inclusion $(41.4 \% \mathrm{DM})$ and short- $(10 \mathrm{~mm})$ or long-chop $(19 \mathrm{~mm})$ length of barley silage. ${ }^{1}$

\begin{tabular}{|c|c|c|c|c|c|c|c|c|}
\hline & \multirow{2}{*}{\multicolumn{4}{|c|}{$\operatorname{Diet}^{1}$}} & \multirow[b]{3}{*}{$\mathrm{SE}$} & \multicolumn{3}{|c|}{ Effect } \\
\hline & & & & & & & & Chor \\
\hline & HSC & HLC & LSC & LLC & & Chop & Concentrate & conc \\
\hline PSPS distribution $^{2}$ & \multicolumn{8}{|c|}{ (\% retained; as-fed basis) } \\
\hline Top screen $(19 \mathrm{~mm})$ & 9.7 & 21.5 & 12.2 & 26.7 & 1.03 & $<0.0001$ & 0.003 & 0.25 \\
\hline Middle screen $(>8 \mathrm{~mm})$ & 42.9 & 45.4 & 48.7 & 52.8 & 2.26 & 0.17 & 0.02 & 0.73 \\
\hline Bottom pan & 47.3 & 33.1 & 39.1 & 25.2 & 0.82 & $<0.0001$ & $<0.0001$ & 0.84 \\
\hline & \multicolumn{8}{|c|}{ (\% retained; DM basis) } \\
\hline Top screen $(>19 \mathrm{~mm})$ & 7.7 & 15.5 & 9.9 & 22.5 & 0.97 & 0.0003 & 0.0004 & 0.03 \\
\hline Middle screen (>8 mm) & 41.4 & 39 & 44.6 & 43.7 & 1.87 & 0.44 & 0.06 & 0.72 \\
\hline Bottom pan & 51.0 & 45.5 & 45.4 & 33.8 & 1.95 & 0.006 & 0.007 & 0.15 \\
\hline & \multicolumn{8}{|c|}{ (NDF retained in fraction; \% DM) } \\
\hline Top screen (>19 mm) & 57.7 & 56.2 & 59.4 & 56.0 & 1.46 & 0.12 & 0.61 & 0.52 \\
\hline Middle screen (>8 mm) & 41.1 & 42.7 & 46.6 & 48.6 & 0.89 & 0.06 & $<0.0001$ & 0.82 \\
\hline Bottom pan & 33.4 & 29.5 & 38.4 & 33.1 & 0.94 & 0.0003 & 0.0003 & 0.47 \\
\hline $\operatorname{peNDF}_{\mathrm{PS}},{ }^{3} \% \mathrm{DM}$ & 18.9 & 21.2 & 24.6 & 29.5 & 0.94 & 0.002 & $<0.0001$ & 0.20 \\
\hline $\operatorname{peNDF}_{\mathrm{NDF}},{ }^{4} \% \mathrm{DM}$ & 25.2 & 29.2 & 30.6 & 34.9 & 0.98 & 0.007 & 0.004 & 0.86 \\
\hline
\end{tabular}

${ }^{1}$ Penn State Particle Separator distributions of experimental diets were calculated for each period $(\mathrm{n}=$ 4) for each treatment.

${ }^{2} \mathrm{HSC}=$ High concentrate, short chop; HLC $=$ high concentrate, long chop; LSC = low concentrate, short chop; and LLC = low concentrate, long chop.

${ }^{3} \mathrm{peNDF}_{\mathrm{DM}}=$ Proportion of DM retained by the 19- and 8-mm PSPS screens multiplied by dietary NDF content.

${ }^{4} \mathrm{peNDF}_{\mathrm{NDF}}=$ Proportion of NDF retained by the 19- and 8-mm PSPS screens. 


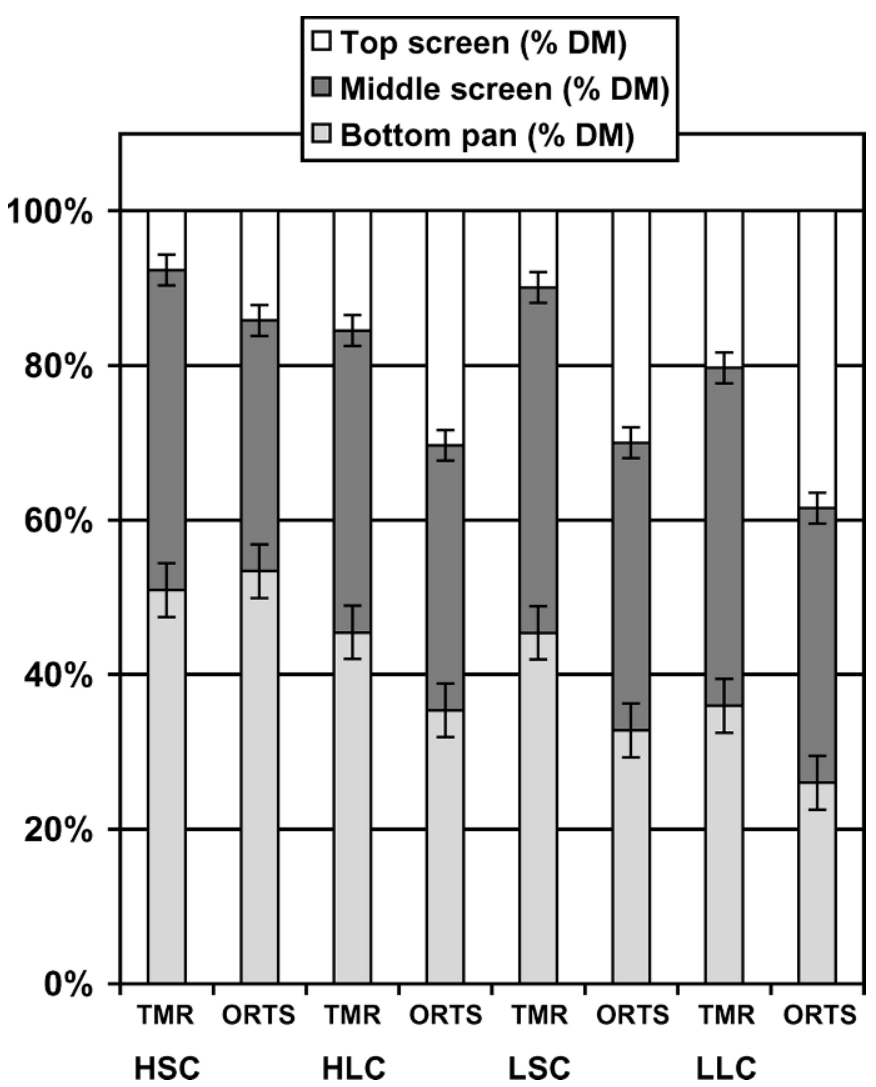

Figure 1. Penn State particle size distribution of diets and orts (DM basis), where diets contained equal inclusion rates of energy supplement and protein supplement within each level of concentrate and varying inclusion rates of barley silage at long and short chops. HSC = high concentrate, short chop; HLC = high concentrate, long chop; LSC = low concentrate, short chop; and LLC = low concentrate, long chop. sani, 1999). The ADIP contents for short- and long-chop barley silages were 9.6 and $7.0 \% \mathrm{CP}$, respectively (Table $3)$. These are lower than the recommended upper limit of $10 \%$ ADIP (Khorasani, 1999) and in the same range as the ADIP contents of the barley silages used in the studies from Soita et al. (2000, 2002).

A recent survey of dairy farms across the province of Manitoba showed that, on average, $42.5 \% \mathrm{DM}$ of barley silage samples passed through the 19- and 8-mm screens of the PSPS, and 49.9\% DM of barley silage samples was retained on the 8-mm screen (Plaizier et al., 2004). In the current study, the long-chop barley silage forage had $4.8 \% \mathrm{DM}$ passed through both PSPS screens, and $60.8 \% \mathrm{DM}$ was retained by the $8-\mathrm{mm}$ screen. The short-chop barley silage forage had $22.4 \%$ DM passed through both PSPS screens, and $68.6 \% \mathrm{DM}$ was retained by the $8-\mathrm{mm}$ screen (Table 5 ). This result shows that even though the middle screen of the PSPS retained the majority of particles at both chop lengths, on average, the barley silages used in this study were of a coarser nature that what is commonly seen across Manitoba.

In a study conducted by Yang et al. (2001), barley silage was also used as a forage source at 2 particle lengths. The longer particle length had $37.0 \% \mathrm{DM}$ passing through the 19- and 8-mm screens of the PSPS, and $57.4 \% \mathrm{DM}$ was retained on the 8-mm screen; the shorter particle length had $38.3 \%$ DM passing through the 19and $8-\mathrm{mm}$ screens, and $61.4 \% \mathrm{DM}$ was retained on the 8-mm screen (Yang et al., 2001). The barley silages used in the current experiment were not as fine and spanned a wider range of lengths than those used by Yang et al. (2001). The particle distribution of the TMR used in the current experiment overlapped in terms of particle size with those used by Kononoff et al. (2000) and Kononoff and Heinrichs (2003b) and was generally

Table 6. Milk production and feed intake of cows fed experimental diets with equal inclusion rates of energy supplement and protein supplement within each level of concentrate and varying inclusion rates of barley silage at long and short chops.

\begin{tabular}{|c|c|c|c|c|c|c|c|c|}
\hline \multirow[b]{3}{*}{ Item $^{2}$} & \multirow{2}{*}{\multicolumn{4}{|c|}{$\operatorname{Diet}^{1}$}} & \multirow[b]{3}{*}{$\mathrm{SE}$} & \multicolumn{3}{|c|}{ Effect } \\
\hline & & & & & & \multirow[b]{2}{*}{ Chop } & \multirow[b]{2}{*}{ Concentrate } & \multirow{2}{*}{$\begin{array}{l}\text { Chop } \times \\
\text { concentrate }\end{array}$} \\
\hline & HSC & HLC & LSC & LLC & & & & \\
\hline DMI, kg/d & 20.1 & 19.4 & 17.7 & 16.9 & 0.34 & 0.03 & 0.0009 & 0.85 \\
\hline Orts, $\%$ of feed provided & 9.8 & 8.0 & 7.1 & 7.0 & 0.73 & 0.23 & 0.03 & 0.27 \\
\hline Milk yield, kg/d & 31.1 & 31.4 & 28.7 & 28.7 & 0.53 & 0.81 & $<0.0001$ & 0.78 \\
\hline \multicolumn{9}{|l|}{ Milk component } \\
\hline Fat, \% & 3.05 & 2.82 & 3.37 & 3.56 & 0.09 & 0.87 & $<0.0001$ & 0.09 \\
\hline Fat yield, kg/d & 0.94 & 0.88 & 0.97 & 1.02 & 0.03 & 0.88 & 0.01 & 0.08 \\
\hline Protein, \% & 3.24 & 3.29 & 3.10 & 3.11 & 0.03 & 0.37 & $<0.0001$ & 0.47 \\
\hline Protein yield, kg/d & 1.01 & 1.03 & 0.89 & 0.89 & 0.02 & 0.59 & $<0.0001$ & 0.60 \\
\hline
\end{tabular}

${ }^{1} \mathrm{HSC}=$ High concentrate, short chop; HLC = high concentrate, long chop; LSC = low concentrate, short chop; and LLC = low concentrate, long chop.

${ }^{2}$ Feed intake and milk production variables were averaged for each animal during each period $(\mathrm{n}=12)$ for each treatment and were analyzed by ANOVA. 
coarser than diets used in the studies by Krause et al. (2002a) and Beauchemin et al. (2003).

\section{DMI}

Reducing the chop length of barley silage from 19 to $10 \mathrm{~mm}$ increased $(P=0.03)$ DMI from 19.4 to $20.1 \mathrm{~kg} /$ $\mathrm{d}$ at the high level of concentrate and from 16.9 to 17.7 $\mathrm{kg} / \mathrm{d}$ at the low level of concentrate inclusion (Table 6). Reducing particle chop length increased DMI in the studies from Soita et al. (2002) and Kononoff and Heinrichs (2003a), decreased DMI in the study from Kononoff et al. (2000), but did not affect DMI in the studies from Yang et al. (2001), Krause et al. (2002a), Beauchemin et al. (2003), Kononoff and Heinrichs (2003b), and Calberry et al. (2003). Of all these studies, the study from Soita et al. (2002) had the lowest concentrate content, and the concentrate inclusion rate in the study from Kononoff and Heinrichs (2003a) was also low compared with other studies. When high forage diets are fed to lactating dairy cows, DMI can be limited by distension of the reticulorumen (Allen, 2000). In this case, a reduction of particle size, resulting in higher rumen passage rate, would allow for greater feed intake (Allen, 2000). Soita et al. (2002) indeed observed that a reduction in forage particle size increased liquid outflow rate and rumen particulate passage rate. However, Kononoff and Heinrichs (2003a) did not find such an effect. Physical fill could be limiting feed intake at the low concentrate inclusion, but, at the high concentrate inclusion, a metabolic, rather than a physical constraint on feed intake, can be expected to be rate limiting (Allen, 2000). Diets in our study were also relatively coarse compared with studies in which no effect of dietary particle size on feed intake was observed, which would explain why reducing dietary particle size resulted in a small increase in feed intake in our study.

The differences in moisture content between the diets containing high concentrate and short- or long-chop barley silage and between the diets containing low concentrate and short- or long-chop barley silage were $<3 \%$. Lahr et al. (1983) found that such a difference in dietary moisture content would have minimal affect on DMI.

\section{Milk Production and Composition}

In our study, dietary particle size did not affect milk yield and milk composition. This confirms the results from Krause et al. (2002a), Beauchemin et al. (2003), and Calberry et al. (2003), who also did not find such an effect. Kononoff and Heinrichs (2003a) observed no effect of dietary particle size on milk yield and milk fat percentage, but did observe a quadratic effect on milk protein percentage. In the study from Yang et al. (2001), forage particle length had no effect on milk yield and tended to reduce milk fat percentage and milk protein percentage. Kononoff and Heinrichs (2003b) found that a reduction in dietary particle size did not affect milk yield, but reduced milk fat percentage and increased milk protein percentage. Kononoff et al. (2000) found that a reduction in barley silage cut length did not affect milk yield and milk composition. Calberry et al. (2003) found that increasing dietary particle size numerically increased milk fat concentration, but did not affect milk yield and milk protein percentage. Despite the discrepancies among studies, a reduction in particle size and peNDF was expected to reduce milk fat percentage. Mertens (1997) determined the relationship between peNDF and milk fat percentage using data from previous studies and found this relationship to be curvilinear. In the lower range of $\operatorname{peNDF}_{\mathrm{M}}(20$ to $22 \% \mathrm{DM})$, a reduction in peNDF caused a larger reduction in milk fat percentage than in higher ranges of peNDF (Mertens, 1997). Dietary peNDF content would be in the upper levels, as calculated by Mertens et al. (1997), in our study, and several other studies in which no effect of peNDF on milk fat percentage was observed. Other reasons that many studies did not observe a significant relationship between peNDF and milk composition might include that few animals were used; diets included large amounts of alfalfa silage and alfalfa hay, which have a higher intrinsic buffering capacity than corn silage (McBurney et al., 1983); and many factors other than dietary particle size and rumen $\mathrm{pH}$, such as dietary fat, can affect milk fat content. (Calberry et al., 2003).

The objective of the study was not to determine the effect of increasing concentrate inclusion on rumen conditions, but the effect of variation in particle size at 2 levels of concentrate inclusion. Increasing the inclusion of concentrate in the diet reduced rumen $\mathrm{pH}$, increased rumen propionate, reduced rumen acetate-to-propionate ratio, increased milk yield, reduced milk fat percentage, increased milk protein percentage, and increased DMI. Such results were expected (NRC, 2001). No interactions between dietary particle size and concentrate level on rumen condition, feed intake, milk yield, and milk protein were observed. The interaction of the effects of chop length and level of concentrate tended to affect milk fat percentage $(P=0.09)$ and milk fat yield $(P=0.08)$. Reducing forage particle length tended to increase $(P=0.11)$ milk fat percentage in the high concentrate diets, but tended to decrease $(P=0.17)$ milk fat percentage in low concentrate diets. A reduction in forage chop length of high concentrate diets is expected to decrease, and not increase, milk fat (Mertens, 1997). The high concentrate diets contained more sodium bicarbonate $(0.7 \% \mathrm{DM})$ than the low concen- 
Table 7. Rumen fluid composition for cows fed experimental diets with fixed inclusion rates of energy supplement and protein supplement within each level of concentrate and varying inclusion rates of barley silage at long and short chops.

\begin{tabular}{|c|c|c|c|c|c|c|c|c|}
\hline \multirow[b]{3}{*}{ Item $^{2}$} & \multirow{2}{*}{\multicolumn{4}{|c|}{$\operatorname{Diet}^{1}$}} & \multirow[b]{3}{*}{$\mathrm{SE}$} & \multicolumn{3}{|c|}{ Effect } \\
\hline & & & & & & \multirow[b]{2}{*}{ Chop } & \multirow[b]{2}{*}{ Concentrate } & \multirow{2}{*}{$\begin{array}{l}\text { Chop } \times \\
\text { concentrate }\end{array}$} \\
\hline & HSC & HLC & LSC & LLC & & & & \\
\hline $\mathrm{pH}$ & 6.37 & 6.35 & 6.51 & 6.53 & 0.03 & 0.97 & $<0.0001$ & 0.38 \\
\hline \multicolumn{9}{|l|}{ VFA, $\mathrm{m} M / \mathrm{L}$} \\
\hline Total & 94.4 & 92.9 & 91.8 & 93.6 & 4.34 & 0.79 & 0.60 & 0.93 \\
\hline Acetate (A) & 56.8 & 55.5 & 58.5 & 58.4 & 3.17 & 0.99 & 0.63 & 0.95 \\
\hline Propionate (P) & 22.1 & 20.9 & 20.0 & 17.7 & 0.68 & 0.04 & 0.009 & 0.49 \\
\hline Butyrate & 12.6 & 12.7 & 12.1 & 12.7 & 0.60 & 0.37 & 0.38 & 0.98 \\
\hline Other & 1.8 & 3.0 & 15.5 & 4.1 & 6.66 & 0.39 & 0.28 & 0.34 \\
\hline A:P & 2.6 & 2.7 & 2.9 & 3.3 & 0.11 & 0.04 & $<0.0001$ & 0.06 \\
\hline Ammonia, mg/dL & 11.1 & 14.5 & 14.0 & 16.3 & 1.14 & 0.01 & 0.03 & 0.50 \\
\hline
\end{tabular}

${ }^{1} \mathrm{HSC}=$ High concentrate, short chop; HLC = high concentrate, long chop; LSC = low concentrate, short chop; and LLC = low concentrate, long chop.

${ }^{2}$ Rumen fluid composition variables were averaged for each animal during each period $(\mathrm{n}=12)$ for each treatment and were analyzed by ANOVA.

trate diets $(0.5 \% \mathrm{DM})$. The difference between the bicarbonate contents of the high and low concentrate diets could have contributed to the interaction of concentrate level and chop length on milk fat.

The increase in DMI caused by the shorter chop length did not result in a milk production response (Table 6), which could be due in part to the short duration of the experimental periods not allowing enough time for animals to respond to dietary changes. In the study from Kononoff and Heinrichs (2003a), an increase in DMI resulting from a reduction in dietary particle size that was larger than that found in our study also did not affect milk yield and milk fat percentage. Lack of milk production response caused by increased DMI and reduction in dietary particle size might also be explained by reduced rumen digestibility. Studies on the effects of dietary particle size on digestibility are conflicting. Yang et al. (2002) and Krause et al. (2002a) found that reduction in dietary particle size did not affect total tract digestibility of DM and NDF. Johnson et al. (2003) found that shorter chop length of corn silage reduced total tract digestibility of OM and NDF. Conversely, Soita et al. (2002) and Kononoff and Heinrichs (2003a) found that reduction in dietary particle size increased apparent digestibility of DM and NDF. Reduction of feed particle size could reduce rumen digestibility if subacute ruminal acidosis is induced (Krajcarski-Hunt et al., 2002), which was not the case in our study. Reduction in feed particle size could increase rumen digestion if it increases the access of rumen bacteria to the feed (Van Soest, 1994), unless rumen particle passage rate is so increased that rumen retention time becomes limiting for fiber digestion. Because of the coarseness of the diets in our study, the latter was not expected.

\section{Rumen Fermentation}

Altering barley silage chop length did not affect rumen $\mathrm{pH}$ at either level of concentrate inclusion (Table 7). Average rumen $\mathrm{pH}$ was 6.36 and 6.52 for the high and low concentrate diets, respectively. Hence, rumen $\mathrm{pH}$ did not drop below 5.6 at 4 to $5 \mathrm{~h}$ after feeding, indicating that subacute ruminal acidosis was not induced (Keunen et al., 2002). As sodium bicarbonate was included in the protein supplement, the high and low concentrate diets contained 0.7 and $0.5 \% \mathrm{DM}$ of sodium bicarbonate, respectively. These inclusions of inorganic buffer would have increased rumen $\mathrm{pH}$, but not so much that removal of the sodium bicarbonate would have resulted in subacute ruminal acidosis (NRC, 2001). Yang et al. (2001) and Kononoff and Heinrichs (2003b) also did not find an effect of dietary particle size on rumen $\mathrm{pH}$, whereas Soita et al. (2002), Krause et al. (2002b), Beauchemin et al. (2003), and Calberry et al. (2003) observed that reducing dietary particle size reduced rumen $\mathrm{pH}$. In the study from Kononoff and Heinrichs (2003a), a quadratic, but not a linear, effect of dietary particle size on rumen $\mathrm{pH}$ was found. This disparity between studies can be explained by the presence of a threshold, only below which peNDF and dietary particle size affects rumen $\mathrm{pH}$. This explains why reduction in particle size affected rumen $\mathrm{pH}$ in fine diets, but not in coarse diets. Despite this, Calberry et al. (2003) found that a reduction in dietary particle size by adding chopped alfalfa hay to a coarse corn silage-based TMR reduced rumen $\mathrm{pH}$. This result might have been caused by factors other than particle size, such as intrinsic buffering capacity, which affects rumen buffering. Corn silage has a lower intrinsic buffering capacity than alfalfa silage (McBurney et al., 1983), facilitating a lower 
rumen $\mathrm{pH}$, thus explaining the effect seen by Calberry et al. (2003) despite using coarser diets. The diets used by Kononoff and Heinrichs (2003b) also used corn silage, but diets were coarser than those used by Calberry et al. (2003), which explains why, in the former study, no effect of dietary particle size on rumen $\mathrm{pH}$ was seen. The high dietary inclusion rate of alfalfa could also explain why, despite small dietary particle sizes, the decline in rumen $\mathrm{pH}$ did not result in subacute ruminal acidosis in the Calberry et al. (2003) study.

Discrepancies in the effects of dietary particle size on rumen $\mathrm{pH}$ between studies might also be due to differences in the monitoring of rumen $\mathrm{pH}$. Yang et al. (2001), Krause et al. (2002a,b), and Beauchemin et al. (2003) used continuous rumen $\mathrm{pH}$ measurement in the ventral sac of the rumen. Kononoff and Heinrichs $(2003 \mathrm{a}, \mathrm{b})$ collected rumen contents for $\mathrm{pH}$ measurement from different sites in the rumen at 2- to 3 -h intervals. In the current study, rumen fluid was collected using an oral probe at $4 \mathrm{~h}$ after feeding. Rumen fluid sampling through a cannula is preferred to rumen fluid collected using an oral probe, but the availability of rumen-fistulated animals often constrains the number of animals available for the experiment. Continuous $\mathrm{pH}$ monitoring is preferred over less frequent determination of rumen $\mathrm{pH}$. However, indwelling $\mathrm{pH}$ probes are normally positioned in the ventral sac of the rumen. Hence, continuous rumen $\mathrm{pH}$ does not take variation between $\mathrm{pH}$ in different sites of the rumen into account (Duffield et al., 2004).

Decreased chop length and increased level of concentrate had no effect on total ruminal VFA but increased ruminal propionate and decreased the acetate-to-propionate ratio (Table 7). Reducing dietary particle size increased total VFA and reduced acetate-to-propionate ratio in the studies from Krause et al. (2002b) and Kononoff and Heinrichs (2003a), decreased total VFA without affecting acetate-to-propionate ratio in the study from Yang et al. (2001), but had no effect on total VFA and acetate-to-propionate ratio in the studies from Beauchemin et al. (2003) and Kononoff and Heinrichs (2003b). These disparities might be explained by the many factors that affect rumen VFA, such as level of concentrate, forage source, concentrate source, rumen volume and flow rate, animal-to-animal variation (Van Soest, 1994), and interactions between these factors and dietary particle size. The absence of an effect of chop length on total rumen VFA could be interpreted as a sign that chop length did not affect the degree of rumen digestion of carbohydrates. However, concentration of VFA in the rumen do not truly reflect production of VFA, as VFA concentration is regulated by the balance between production and absorption of VFA, as well as rumen fluid pool size and turnover (Van Soest, 1994).
Reduction in dietary particle size decreases liquid passage rate and volume of liquid digesta in the rumen because of a reduction in saliva production (Yang et al., 2001, 2002, Krause et al., 2002a).

A decrease in rumen ammonia concentration was found when barley silage chop length was reduced from 19 to $10 \mathrm{~mm}$ (Table 7). Crude protein was significantly higher in the long-chop barley silage as well as in diets that contained long-chop barley silage (Tables 1 and 3). This could account for the increase in rumen ammonia concentration when long-chop barley silage was fed. Yang et al. (2001), Beauchemin et al. (2003), and Kononoff and Heinrichs (2003a,b) found no effect on rumen ammonia when forage particle size was reduced. As a result, it is believed that differences in protein contents between diets, rather than differences in dietary particle size, were responsible for differences in rumen ammonia. Rumen ammonia concentration increased as concentrate inclusion rate decreased (Table 7). Dry matter intake increased when the high concentrate diets were fed. As feed intake and passage rate increase, then rumen digestion, more specifically, protein digestion, decreases resulting in diminished ruminal ammonia production (NRC, 2001). Increased levels of bypass protein were fed in the high concentrate diets compared with the lower concentrate diets, resulting in more protein escaping ruminal degradation.

\section{CONCLUSIONS}

Reducing the chop length of barley silage from 19 to $10 \mathrm{~mm}$ reduced the proportion of the TMR retained by the 19- and 8-mm screens of the PSPS from 54.5 to $49.1 \% \mathrm{DM}$ at the high concentrate inclusion $(58.0 \% \mathrm{DM}$ concentrate) and from 66.2 to $54.5 \% \mathrm{DM}$ at the low concentrate inclusion (41.4\% DM concentrate). This reduction in chop length increased DMI across concentrate inclusion rates from 18.1 to $18.9 \mathrm{~kg} / \mathrm{d}$ but did not affect milk yield, milk composition, rumen $\mathrm{pH}$, and rumen propionate. Reduction of chop length also increased rumen propionate and reduced rumen acetateto-propionate ratio and rumen ammonia. Reducing barley silage chop length to $10 \mathrm{~mm}$ had no detrimental effects on rumen parameters or milk production for lactating cows consuming TMR containing 41.4 to $58.0 \%$ barley grain based concentrate.

\section{REFERENCES}

Allen, M. S. 2000. Effects of diet on short-term regulation of feed intake by lactating dairy cattle. J. Dairy Sci. 83:1598-1624.

Association of Official Analytical Chemists. 1990. Official Methods of Analysis. 15th ed. AOAC, Arlington, VA.

Beauchemin, K. A. 1991. Effects of dietary neutral detergent fiber concentration and alfalfa hay quality on chewing, rumen function, and milk production of dairy cows. J. Dairy Sci. 74:3140-3151. 
Beauchemin, K. A., and L. M. Rode. 1997. Minimum versus optimum concentrations of fiber in dairy cow diets based on barley silage and concentrates of corn or barley. J. Dairy Sci. 80:1629-1639.

Beauchemin, K. A., W. Z. Yang, and L. M. Rode. 2003. Effects of particle size of alfalfa based dairy cow diets on chewing activity, ruminal fermentation, and milk production. J. Dairy Sci. 86:630-643.

Calberry, J. M., J. C. Plaizier, M. S. Einarson, and B. W. McBride. 2003. Replacing chopped alfalfa hay with alfalfa silage in a high barley concentrate total mixed ration. J. Dairy Sci. 86:3611-3619.

Duffield, T., J. C. Plaizier, R. Bagg, G. Vessie, P. Dick, J. Wilson, J. Aramini, and B. McBride. 2004. Comparison of techniques for measurement of rumen $\mathrm{pH}$ in lactating dairy cows. J. Dairy Sci. 87:59-66.

Erwin, E. S., G. J. Marco, and E. M. Emery. 1961. Volatile fatty acids analysis of blood and rumen fluid by gas chromotography. J. Dairy Sci. 44:1768-1776.

Heinrichs, J. 1996. Pages 1-9 in Evaluating Particle Size of Forages and TMRs Using the Penn State Particle Size Separator. The Pennsylvania State University, College Park.

Johnson, L. M., J. H. Harrison, D. Davidson, W. C. Mahanna, and K. Shinners. 2003. Corn silage management: Effects of hybrid, chop length, and mechanical processing on digestion and energy content. J. Dairy Sci. 86:208-261.

Keunen, J. E., J. C. Plaizier, I. Kyriazakis, T. F. Duffield, T. M. Widowski, M. I. Lindinger, and B. W. McBride. 2002. Effects of a subacute ruminal acidosis model on the diet selection of dairy cows. J. Dairy Sci. 85:3304-3313.

Khorasani, G. R. 1999. Barley silage: From seed to animal. Available: http://www.westerndairyscience.com/html/ U\%20of\%20A\%20articles/html/BarleySilage.html. Accessed Sep. $22,2003$.

Koenig, K. M., K. A. Beauchemin, and L. Rode. 2003. Effect of grain processing and silage on microbial protein synthesis and nutrient digestibility in beef cattle fed barley-based diets. J. Anim. Sci. 81:1057-1067.

Kononoff, P. J., and A. J. Heinrichs. 2003a. The effect of reducing alfalfa haylage particle size on cows in early lactation. J. Dairy Sci. 86:1445-1457.

Kononoff, P. J., and A. J. Heinrichs. 2003b. The effect of corn silage particle size and cottonseed hulls on cows in early lactation. J. Dairy Sci. 86:2438-2451

Kononoff, P. J., A. F. Mustafa, D. A. Christensen, and J. J. McKinnon. 2000. Effects of barley silage particle length and effective fiber on yield and composition of milk from dairy cows. Can. J. Anim. Sci. 80:749-752.

Krajcarski-Hunt, H., J. C. Plaizier, J.-P. Walton, R. Spratt, and B. W. McBride. 2002. Short communication: Effect of subacute ruminal acidosis on in situ fiber digestion in lactating dairy cows. J. Dairy Sci. 85:570-573.
Krause, K. M., D. K. Combs, and K. A. Beauchemin. 2002a. Effects of forage particle size and grain fermentability in midlactation cows. I. Milk production and diet digestibility. J. Dairy Sci. $85: 1936-1946$.

Krause, K. M., D. K. Combs, and K. A. Beauchemin. 2002b. Effects of forage particle size and grain fermentability in midlactation cows. I. Ruminal $\mathrm{pH}$ and chewing activity. J. Dairy Sci. 85:1947-1957.

Lahr, D. A., D. E. Otterby, D. G. Johnson, J. G. Linn, and R. G. Lundquist. 1983. Effects of moisture content of complete diets on feed intake and milk production by cows. J. Dairy Sci. 66:1891-1900.

McBurney, M. I., P. J. Van Soest, and L. E. Chase. 1983. Cation exchange capacity and buffering capacity of neutral detergent fibres. J. Sci. Food Agric. 34:910-916.

McRae, J. C., and D. G. Armstrong. 1968. Enzyme methods for determination of $\alpha$-linked glucose polymers in biological materials. J. Sci. Food Agric. 19:578-581.

Mertens, D. R. 1997. Creating a system for meeting the fiber requirements of dairy cows. J. Dairy Sci. 80:1463-1481.

National Research Council. 2001. Nutrient Requirements of Dairy Cattle. 7th rev. ed. Natl. Acad. Sci., Washington, DC.

Nocek, J. E. 1997. Bovine acidosis: Implications on laminitis. J. Dairy Sci. 80:1005-1028.

Novozamsky, I., R. Van Eck, J. C. H. Schouwenburg, and F. Walinga 1974. Total nitrogen determination in plant material by means of the indole-phenol blue method. Neth. J. Agric. Sci. 22:3-5.

Plaizier, J. C., T. Garner, T. Droppo, and T. Whiting. 2004. Nutritional practices on Manitoba dairy farms. Can J. Anim. Sci. (in press).

SAS User's Guide. Statistics. Version 6 edition. 1990. SAS Inst., Inc., Cary, NC.

Soita, H. W., D. A. Christensen, and J. J. McKinnon. 2000. Influence of particle size on the effectiveness of the fiber in barley silage. J. Dairy Sci. 83:2295-2300.

Soita, H. W., D. A. Christensen, J. J. McKinnon, and A. F. Mustafa. 2002. Effects of barley silage of different theoretical cut length on digestion kinetics in ruminants. Can. J. Anim. Sci. 82:207-213.

Van Soest, P. J. 1994. Nutritional Ecology of the Ruminant. 2nd ed. Cornell Univ. Press, Ithaca, NY.

Van Soest, P. J., J. B. Robertson, and B. A. Lewis. 1991. Methods for dietary fiber, neutral detergent fiber, and nonstarch polysaccharides in relation to animal nutrition. J. Dairy Sci. 74:35833597.

Yang, W. Z., K. A. Beauchemin, and L. M. Rode. 2001. Effects of grain processing forage to concentrate ratio, and forage particle size on rumen $\mathrm{pH}$ and digestion by dairy cows. J. Dairy Sci. 84:2203-2216.

Yang, W. Z., K. A. Beauchemin, and L. M. Rode. 2002. Effects of particle size of alfalfa-based diets on site and extent of digestion. J. Dairy Sci. 85:1958-1968. 